Original Article

\title{
Study of lichen (Usnea spp.) as a traditional medicine in Bogor, West Java
}

\author{
Miftahul Jannah ${ }^{1 *}$, Nida Afifah ${ }^{1}$, Muhammad Rifqi Hariri ${ }^{2}$, Anisa Rahmawati ${ }^{1}$, Tri Yuni Indah Wulansari \\ ${ }^{1}$ Biology Department, As-Syafi iyah Islamic University, Jakarta, Indonesia \\ ${ }^{2}$ Research Center for Plant Conservation and Botanic Gardens, Indonesian Institute of Sciences \\ ${ }^{3}$ Research Center for Biology, Indonesian Institute of Sciences
}

\begin{abstract}
Usnea is a genus of lichen used as a traditional medicine in the form of herbal medicine. The people of Bogor know Usnea as kayu angin, antanan, and cecenetan. Usnea used in herbal medicine is often considered only one species, even though there are many different species. Information about the traditional use of Usnea is essential to increase the widespread use of natural resources. This study purposed to determine the types of Usnea and their use as traditional medicine by the people of Bogor city. A total of 30 respondents were interviewed using semi-structured questionnaires and personal interviews. Data were analyzed descriptively based on the results of exploration and interviews with respondents. The results showed that six species of Usnea had been used for treatment, including U. intermedia, U. esperantiana, U. hesperina, U. pectinata, U. fragilescens, and U. baileyi. Usnea is used for health herbs, after childbirth, colds, gout, and herbal mixtures in all medications
\end{abstract}

Keywords: Lichen, Usnea, Bogor, traditional medicine

Received: 27 October 2020 Revised: 21 December 2020 Accepted: 25 December 2020

\section{Introduction}

Medicinal plants are one of the important components in medicine and have been used by the Indonesian people for centuries in the form of herbs to treat various health problems known as Jamu. Jamu is a cultural wealth of the Indonesian nation that needs to be preserved, and its existence must be preserved amid the proliferation of chemical-based drugs, which have dangerous side effects in the long term for humans. The development of natural medicines does need to get greater attention not only because of its open development potential but also because the market demand for raw materials for these traditional medicines continues to increase for domestic and international needs. Data on the herbal medicine market in the Indonesian Ministry of Health shows the increase, from Rp. 6 trillion in 2007, to Rp. 13.2 trillion in 2012 (Kemenkes, 2016).

One species of a medicinal plant that is widely used by the public in herbal formulas is Usnea. Usnea is a genus of lichen and has been used as a medicine for thrush, dysentery, colds, rashes, seizures, menstrual pain, and to facilitate childbirth (Jannah, 2020). The culture of drinking herbal medicine is more synonymous with Javanese culture; however, herbal medicine is not only consumed by Javanese people. The existence of herbal medicine has spread in various regions, one of which is the Sundanese community. The results of Noer's research

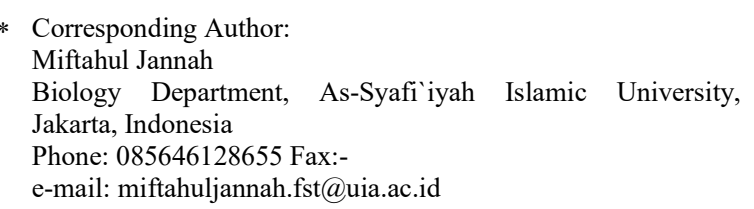

(2007) state that the Sundanese people, in Bandung and Sukabumi, use Usnea as a simplicia in 27 formulas for the boiled herbal medicine. However, data on the use of Usnea in Bogor has never been reported.

Bogor city is a closely related area to Sundanese culture. Besides, it is also known for the tradition of drinking herbal medicine. This is indicated by the discovery of several kinds of simplicia, especially Usnea, which is sold in the traditional market of Bogor city. However, the species of Usnea used in the Bogor area have never been identified and reported. The people of Bogor know Usnea as a type of plant, even though there are many species in it. Usnea species at a glance have very similar shapes, so that people do not know the specific species of Usnea when making herbal medicine (Jannah, 2014). Excessive use of certain species will threaten their availability in nature. Information about the traditional use of Usnea is essential to increase the widespread use of natural resources. Based on the explanation above, it is necessary to conduct research related to the identification and use of Usnea in the community of the Bogor area. This information can be used as a basis for further research, especially in the pharmaceutical field as an option in the development of medicinal raw materials.

\section{Methods}

The research samples were taken from several traditional markets in the city of Bogor. Sampling was done by purposive sampling (Tiro \& Arbianingsih, 2011). Ethnobotany data were obtained through direct observation and supported by interviews of 30 respondents (Fitriana, 2017). The respondents consisted of herbal medicine sellers, herbal mixers, and Bogor 
local people. Interviews were conducted in a semistructured manner with a questionnaire guide (the questionnaire was validated using validity content with expert judgment). The information collected is Usnea's local name, source of origin, use, parts used, how to mix herbs, knowledge of herbal medicine, and where the knowledge of utilization comes.

The identification of Usnea spp. was based on morphological, anatomical and microchemical characters. Morphological observations included the colour of the talus, the colour of the base of the talus, the shape of the talus, the shape of the branching of the talus, the central axis, the type of fibrils, papillae, type and colour of the medulla, pseudocpyhellae, soralia type, isidia type, and apothesis. Anatomical observations were made by observing longitudinal sections of the medulla and central axis. Micromia observations were carried out by slicing lichen talus and observing the colour change in the medulla after dripping with Kaliumhydroxid Platzchen, and Calcium Hypochlorite. The identification of microcrystals used various reagents i.e. GAW (H2O:glycerol:ethanol=1:1:1), GE (acetic acid:glycerol $=1: 3$ ), An (aniline:glycerol:ethanol $=1: 2: 2$ ), dan oT (otoluidine: glycerol:ethanol=1:2:2). The species identification was carried out using identification keys from several researchers (Jannah, 2014; Ohmura, 2001; Ohmura, 2012; and Randlane, 2009). Data were analyzed descriptively based on the results of exploration and interviews.

\section{Results}

There are six Usnea species that consist of two subgenera, namely Usnea and Eumitria found in traditional markets in Bogor. Four species belong to subgenus Usnea, namely $U$. intermedia, $U$. esperantiana, $U$. hesperina, and U. fragilescens, while two species belong to subgenus Eumitria, namely $U$. pectinata and $U$. baileyi. The species description is as follows:

\section{Usnea intermedia (A. Massal.) Jatta}

thallus brownish green, shrubby to subpendant, anisotomic-dichotomous, base usually black, without soredia and isidia, apothecia green, pseudocyphellae present, fibril and papillae mostly irregularly distributed on the whole thallus, medulla loose, central axis solid with unpigmented. Chemical test in medulla are C-, K-, yellow, $\mathrm{P}+$ orangish yellow, contain salazinic acid, usnic acid,fumarprotocetraric acid, usnic acid, psoromic acid, lobodirin, caperatic acid, grayanic acid, leucotylin, and alectorialic acid (Fig. 1).

\section{Usnea esperantiana Clerc}

Thallus yellowish green or brownish yellow with shiny surface, erect-shrubby, anisotomic-dichotomous, with green soredia, base green brown, sausage shaped, perforated, papillae small and sparsely, apothecia present, branchlets rather sparse, fibril short and irregularly distributed, soralia rounded and white, isidiomorphs absent, pseudocyphellae absent, medulla dense, central axis solid. Chemical test in medulla are $\mathrm{C}-, \mathrm{K}+$ red, $\mathrm{P}+$ red, contain salazinic acid, norstictic acid, galapagin, retigeric acid, salazinic acid, and imbricaric acid (Fig. 2).

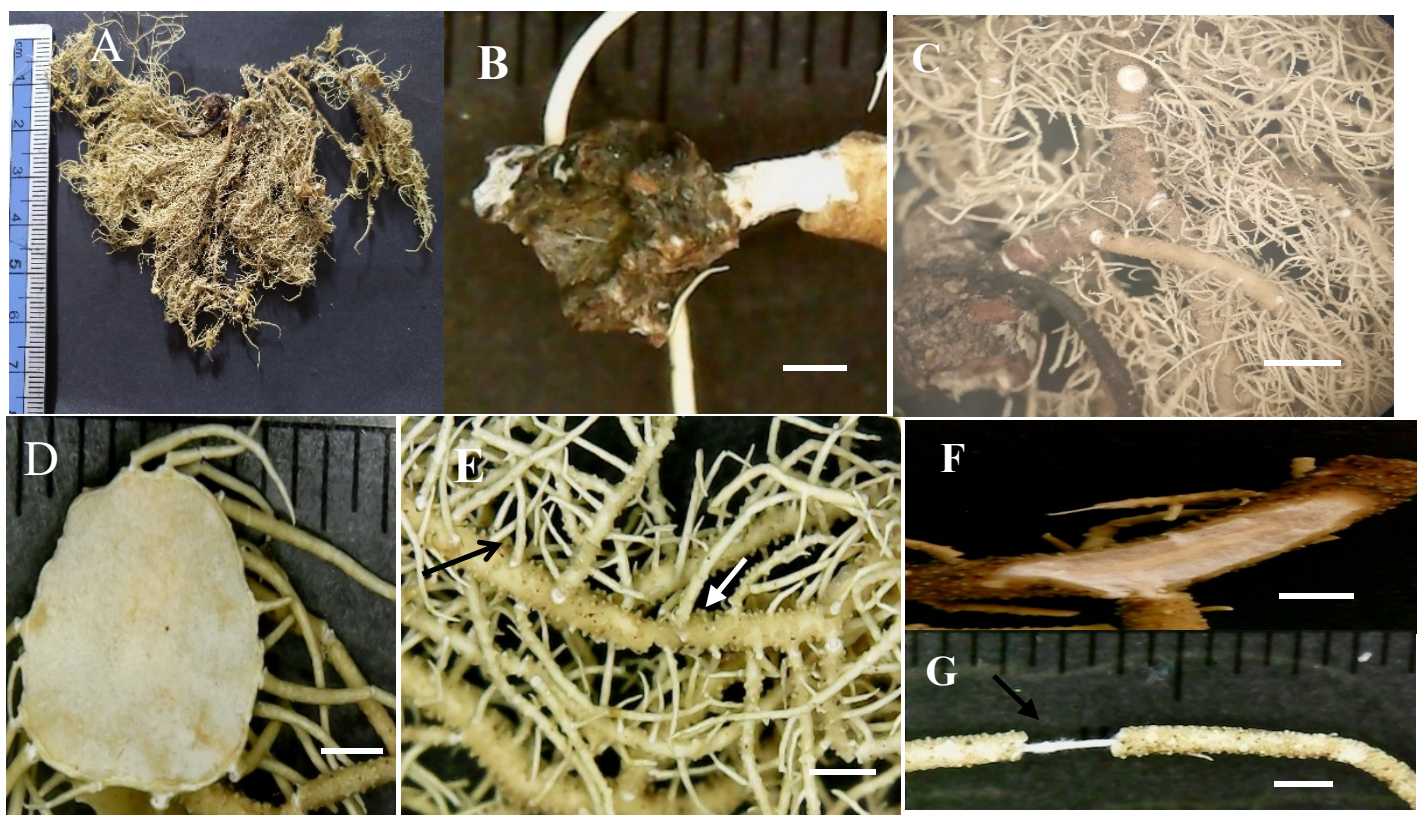

Figure 1. Morphological structure of $U$. intermedia: A. Morphology of thallus, B. Base , C. Surface of the thallus, 2 mm bar, D. Apotecia, E. Fibril (black arrow) \& papillae (white arrow), F. Medula loose type, G. Central axis. Bar $1 \mathrm{~mm}$. 


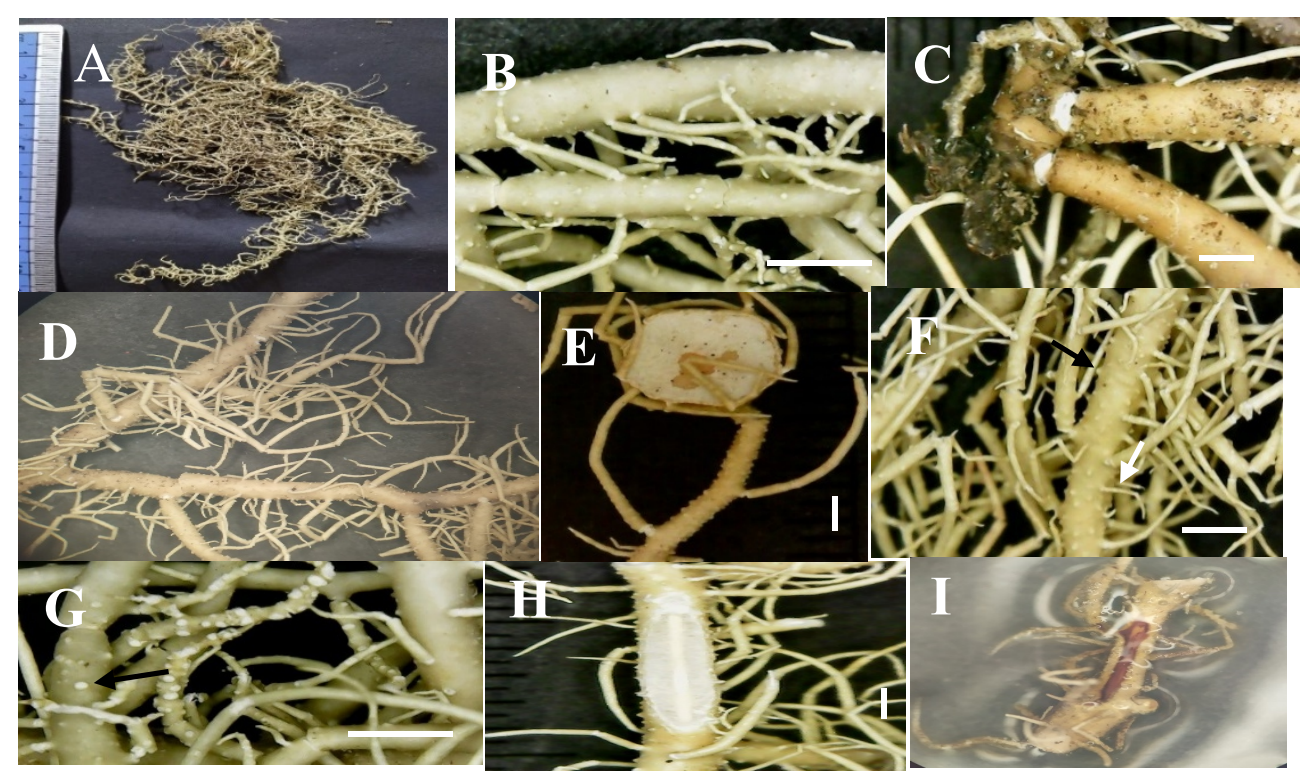

Figure 2. Morphological structure of $U$. esperantiana. A. Morphology of thallus, B. Thallus surface, C. Base, D. Branch type. bar $2 \mathrm{~mm}$, E. Apothecia, F. Fibril (white arrow) \& papillae (black arrow), G. Soralia, H. Medulla loose type, I. chemical test (K+red). Bar $1 \mathrm{~mm}$.

\section{Usnea hesperina Motyka}

Thallus yellowish-green, pendent, isotomicdichotomous, base pale to brown, strong annular cracks, slightly foveolate, fibril sparse to relatively abundant, segment present, soralia white, rounded to punctiform and abundant, pseudocyphellae present, apothecia absent, medulla compact, central axis solid. Chemical test in medulla are $\mathrm{C}-, \mathrm{K}-, \mathrm{P}+$, contain usnic acid, stictic acid, didymic acid, atranorin, protocetraric acid, salazinic acid, and 4-0 metylphysodic acid (Fig. 3).

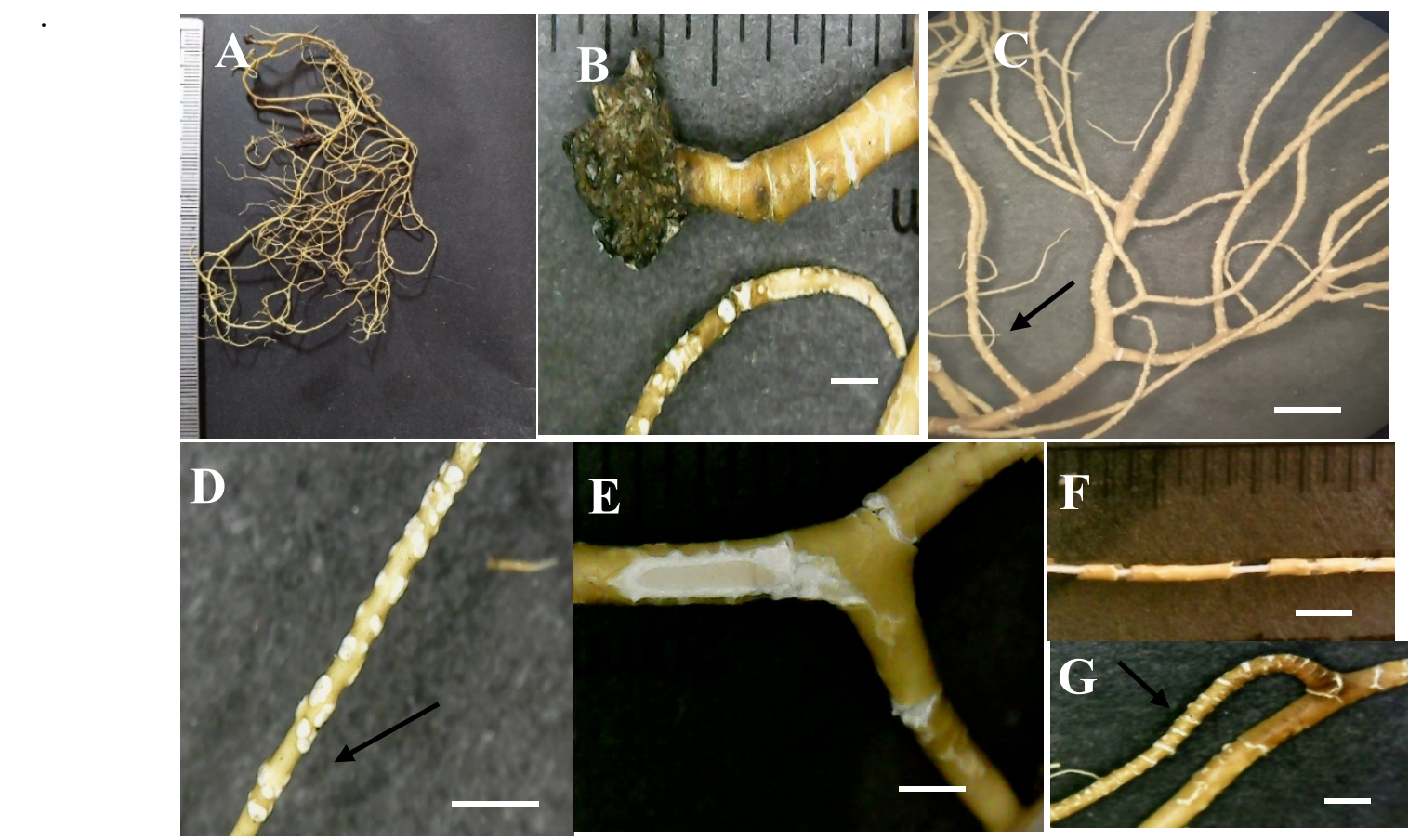

Figure 3. Morphological structure of U. hesperina. A. Morphology thallus, B. Base, C. Branch type, bar 2 mm, D. Soralia, E. Medulla compact type,

F. Central axis, G. Segment. Bar $1 \mathrm{~mm}$.

\section{Usnea pectinata Taylor}

Thallus green, pendent, isotomic dichotomous with decorticated on main branches, base dark brown to black, apothecia present, fibril long and irregularly distributed, the punctiform maculae on lateral branches, medulla compact, central axis solid. Chemical test in medulla are $\mathrm{C}-, \mathrm{K}+$ yellow to red. Contain usnic acid, stictic acid, psoromic acid, acetylportentol, and hiascic acid (Fig. 4). 


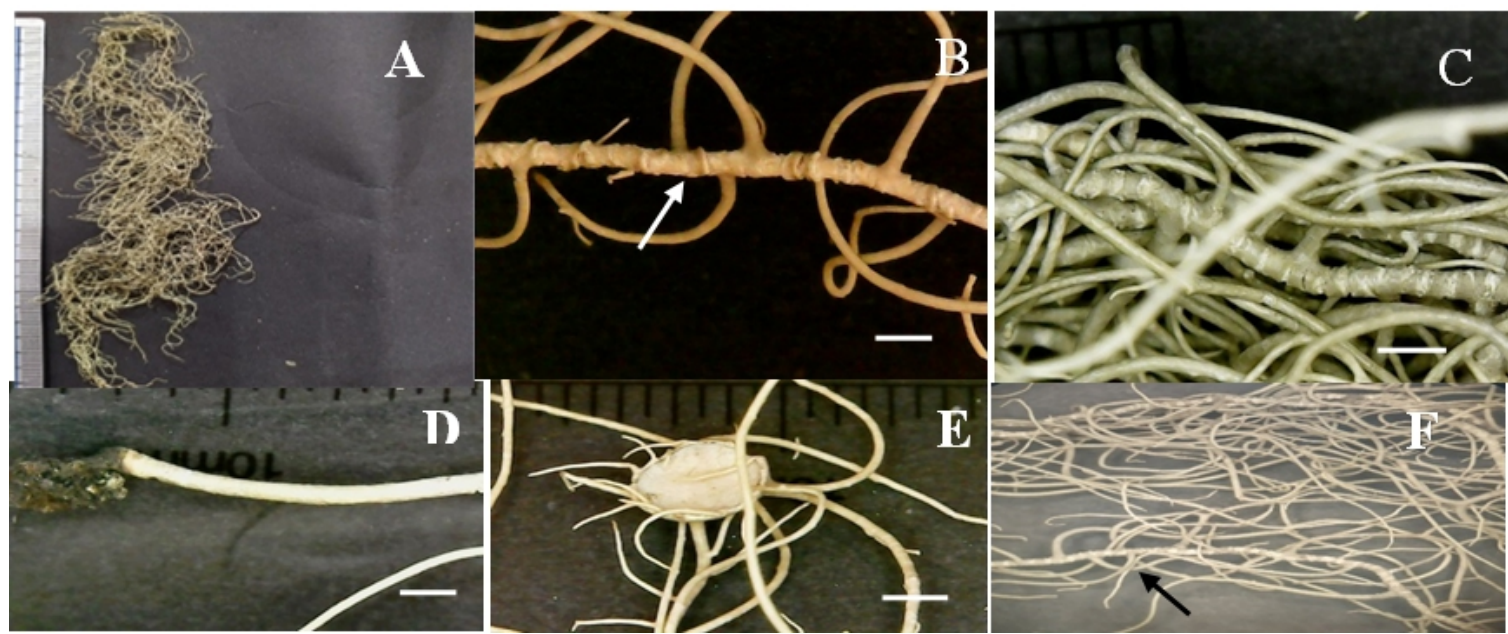

Figure 4. Morphological structure U. pectinata. A. Morphology thallus, B. Decorticated on thallus, C. Medulla compact type, D. Base, E. Apothecia, F. Fibril. Bar 1mm.

\section{Usnea fragilescens Hav. ex Lynge}

Thallus brownish yellow, erect-shrubby to subpendent, isotomic-dichotomous, base pale brown or black, fibril rarely and unevenly distributed, soralia rounded, papillae densely and regularly distributed, isidia white and rarely, segment terete, pseudocyphellae absent, apothecia absent, medulla loose to dense, central axis solid and unpigmemted, Chemical test in medulla are C-, $\mathrm{K}+$ yellow to red, P+yellow. Contain psoromic acid, usnic acid, stictic acid, salazinic acid, and norstictic acid (Fig. 5).
Thallus dark green to grayish, erect-shrubby to subpendent, anisotomic-dichotomous, base black, fibril numerous and disturbed, papillae sparse to dense on main branches, pseudocyphellae present, Medulla dense or compact with yellow, central axis fistulose, Apothecia rare. soralia absent, Chemical test in medulla are C-, $\mathrm{K}+$ yellow to red, $\mathrm{P}+$. Contain eumitrin, zeorin, protocetraric acid, norstictic acid, diffractaic acid, and thamnolic acid (Fig. 6).

\section{Usnea baileyi (Stirt.) Zahlbr.}

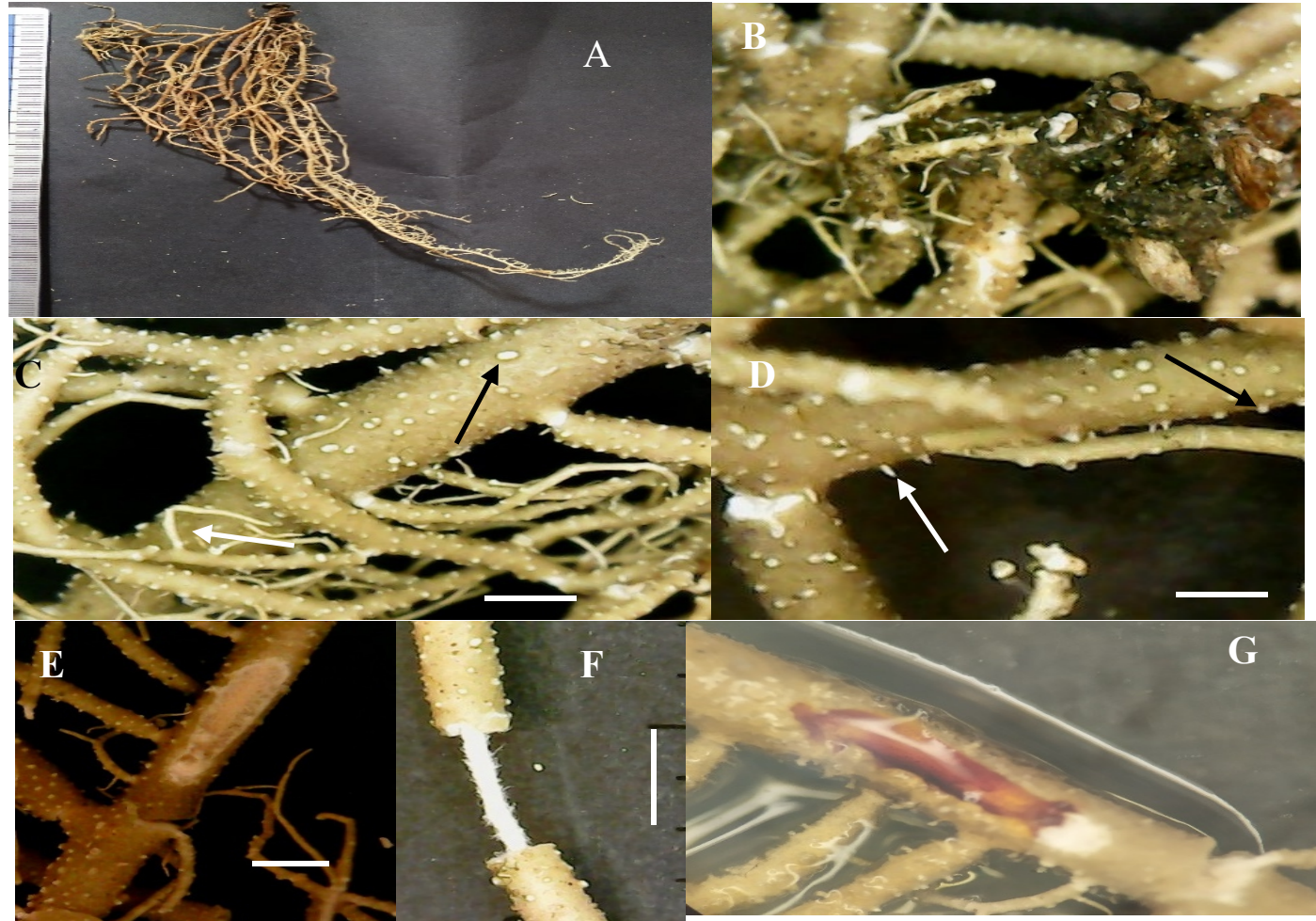

Figure 5. Morphological structure U. fragilescens. A. Morphology thallus, B. Base, C. Soralia (black arrow) \& fibril (white arrow), D. Isidia (white arrow) \& papilae (black arrow), E. Medulla loose type , F. Central axis. G. Chemical test $(\mathrm{K}+)$. Bar $1 \mathrm{~mm}$. 


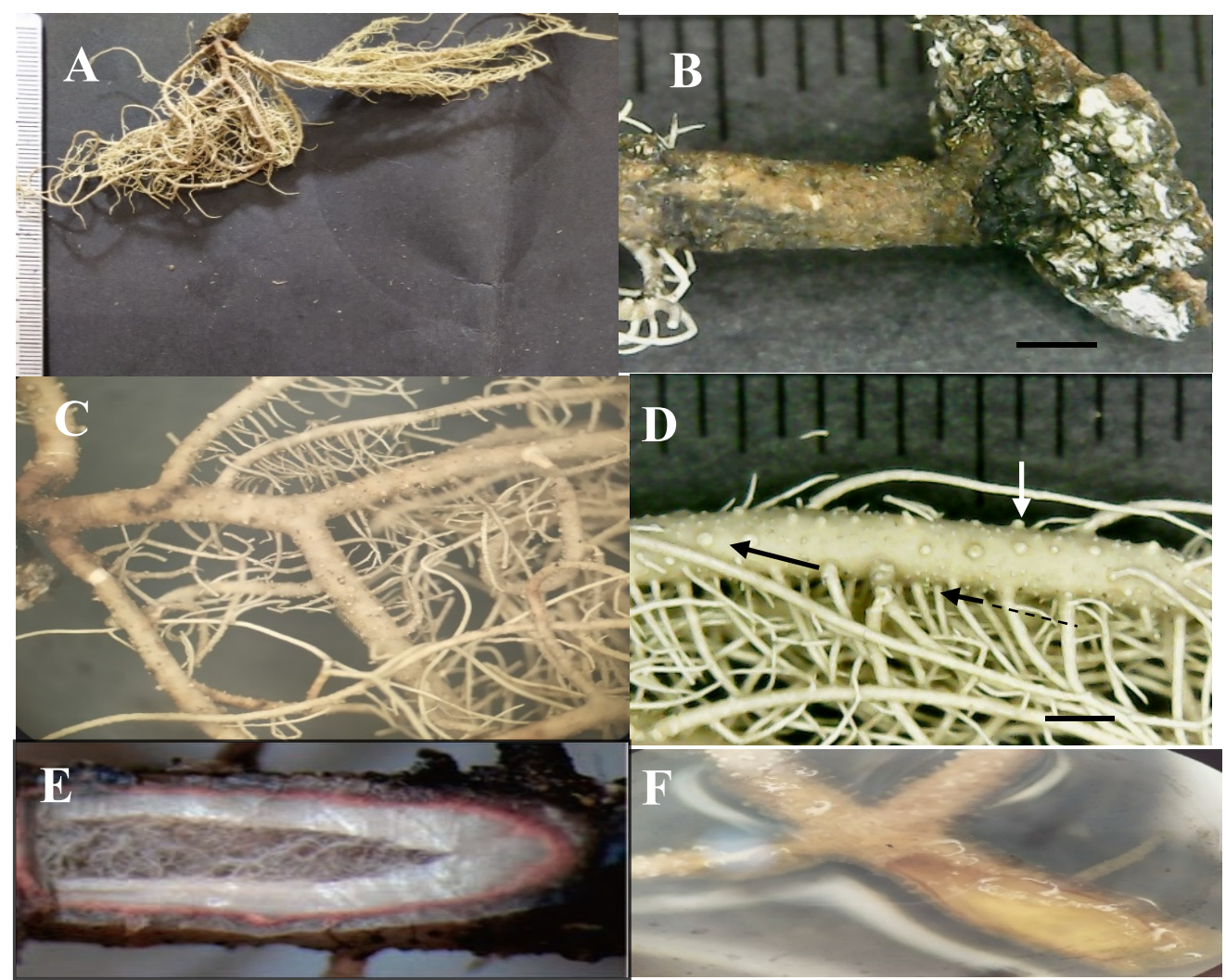

Figure 6. Morphological structure U. baileyi. A. Morphologi thallus, B. Base, C. Branch type, bar $2 \mathrm{~mm}$, D. Fibril, papillae (white arrow) \& soralia (black arrow), E. Medulla and central axis fistulose, F. Chemical test $(\mathrm{K}+)$. Bar $1 \mathrm{~mm}$.

\section{Discussion}

\section{Utilization of Usnea spp. in the traditional market of Bogor City}

The results of the interview indicated that the use of herbs as medicine was still in demand reinforced by the statement of the respondents who sell herbal medicine, that the people of Bogor still consume herbal medicine. It is found that herbal medicine sellers in the form of concoctions. The community recognizes Usnea as having different local names, the "peracik" and herbal medicine sellers recognize it as "kayu angin". At the same time, people call it "antanan" or "cecenetan" but most do not know the local name Usnea. This shows that the level of knowledge of the local name Usnea in the Bogor community is shallow. Even though the people of Bogor do not recognize Usnea, people usually consume herbal concoctions whose raw materials are Usnea, such as gout herbal medicine, health herbal medicine and after giving birth. Also, the community acknowledges that they feel the benefits after consuming herbal medicine, and they feel that their body is getting better.

The community has acquired knowledge and skills in making herbal medicine through hereditary inheritance from previous people. Usnea is used either in the form of a single simplicia or mixed with other ingredients. The public knows Usnea as a species, so the species in the herbal concoctions are mixed randomly. People believe that all diseases are caused by excess wind in the body, so Usnea is found(as a carminative (Maulidiyah, 2016) in all herbal concoctions. For example, in the composition of herbal medicine after giving birth, Usnea simplicia is found with several other ingredients that have a synergistic function in medicine. The ingredients consist of Curcuma domestica, which is useful as a freshener and body warmer, so that it will affect the mother's condition for breastfeeding, Zingiber zerumbet, Terminalia chebuca, and Strobilanthes crispa to increase blood and restore the condition of women after childbirth and Curcuma xanthorriza to increase milk production (Handayani, 2008).

Usnea, in the form of a single simplicia is found to treat colds. Some people combine it with Helicteres isora to reduce pain (analgesic). An excellent herbal concoction should have a synergistic effect from each of the components mixed to provide maximum effectiveness in treatment and not cause antagonistic effects (Mulyani, 2016). The utilization of Usnea species in the Bogor area can be seen in Table 1.

All simplicia conditions found in the herbal concoctions are in good condition. The condition indicated by several characteristics that meet the sound quality of simplicia are easy to knead, not mouldy, and smells like fresh ingredients (Herawati, 2012). The method of processing herbal medicine is done by boiling simplicia until the water boils in $1 \mathrm{~L}$ of water for 5-10 min over medium heat. The aims to move the active substance from the simplicia into a water solution, and its properties are not lost for treatment. According to Tilaar (2010), how to process herbal concoctions by boiling can speed up the healing process because they are processed directly in the body's metabolism. The 
recommendation of herbal formers, herbal medicine should be consumed twice a day for three days a week.

The herbal mixers mix all species of Usnea into all kinds of herbal concoctions as the main ingredient. Scientific research showed that the active compounds in the Usnea thallus contain lecanoric acid and usnic acid which are useful as antioxidants, antibiotics, antifungals, antiviral, anti-inflammatory, analgesic, antipyretic, antiproliferative, and cytotoxic effects (Luo, 2009; Backorova, 2012). The results of research that were successfully carried out in experiments with rat test animals showed that usnic acid contained in Usnea diffracta had activity as a pain reliever and also reducing fever (Septiana, 2011).

Several species of Usnea are also used as ingredients in the manufacture of Standardized Herbal Medicines, both for internal and external drug consumption in the health and beauty fields. The examples of products containing Usnea are repellent, oradiar, janna tea, and herbal skin. In foreign countries, some products have used Usnea specifically at the species level, for example, "Usnea barbue" from U. barbata extract. Septiana (2011) states that the results of research on lichen extract from clinical trials have an activity that is more effective and relatively safe compared to chemical drugs used in general by the public. It can be seen that lichen has excellent potential to be developed into a medicinal substance.

\section{Origin of Acquisition, Constraints and Usnea Conservation Recommendations}

The community suggests that Usnea, which is used for the concoction of herbal medicine comes from Kediri and Solo. Usnea distribution channel originates from Kediri or Solo then sent to Jakarta first as the centre after that it is sent to the city of Bogor. Starting in 2017 the community has complained about the availability of Usnea, so that there are several packaged herbal concoctions without Usnea. This is because Usnea is getting challenging to find. This shows that Usnea has eroded its existence in nature so that cultivation to maintain its sustainability needs to be done immediately.

Usnea, which is an epiphytic plant, has its risks. The damage or loss of the host where it grows, fires, environmental pollution, land clearing are some of the causes of reduced Usnea in nature (Brodo, 2001). Besides, taking certain species of Usnea excessively in nature to be used as medicinal ingredients is also feared to have a role in threatening its erosion in nature.

It is necessary to make efforts to obtain Usnea in large quantities and in a faster time compared to taking directly from nature. One way that can be done is by applying tissue culture techniques. In general, lichen grown using tissue culture techniques will grow faster than those grown naturally (Behera et al., 2009). Lichen culture will also produce the same active compounds under natural growing conditions and in more significant quantities. The results showed that the culture results of Usnea ghattensis with modified growth conditions were able to produce more excellent usnic acid than natural growth conditions (Behera et al., 2009). Research on lichen culture has been developed in Australia, while in other countries it has not been developed, especially in Indonesia. The tissue culture technique for lichen is generally similar to that of plants. A possible way to develop culture techniques on lichen in Indonesia to support the development of lichen as a medicinal ingredient and at the same time maintain the presence of lichen, especially Usnea.

In conclusion, there are six species of Usnea found and utilized in the Bogor area which comes from into two sub-genera, namely subgenus Usnea (Usnea intermedia, $U$. esperantiana, $U$. hesperina, and $U$. fragilescens) and subgenus Eumitria (U. pectinata and $U$. baileyi). People use Usnea as a component of all herbal medicine, such as after giving birth, catching colds and a mixture of ingredients for the treatment of all diseases. Information about the use of Usnea as traditional medicine can be used as the basis for further research in various related fields.

Table 1. Spesies and uses of Usnea

\begin{tabular}{ccll}
\multicolumn{1}{c}{ Table 1. Spesies and uses of Usnea } & & \multicolumn{1}{c}{ Utilization } \\
\hline No & Species & After giving birth and cold & Processing method \\
\hline 1 & U. pectinata & A mixture of ingredients for the treatment of all diseases & Boiled \\
\hline 2 & U. esperantiana & A mixture of ingredients for the treatment of all diseases & Boiled \\
\hline 3 & U. hesperina & $\begin{array}{l}\text { Gout and a mixture of ingredients for the treatment of all } \\
\text { diseases }\end{array}$ & Boiled \\
\hline 5 & U. intermedia & A mixture of ingredients for the treatment of all diseases & Boiled \\
\hline 6 & U. baileyi & $\begin{array}{l}\text { Health herbs and a mixture of ingredients for the treatment } \\
\text { of all diseases }\end{array}$ \\
\hline
\end{tabular}

\section{Acknowledgement}

The authors gratefully acknowledge the financial support of the Ministry of Research, Technology, and Higher Education. We also thank all those who have helped in this research completion.

\section{References}

Backorova, M., R, Jendzelovsky, M., Kello, Backor, M., J, Mikes, \& Fedorocko,P. (2012). Lichen Secondary Metabolites are Responsible for Induction of Apoptosis in HT-29 and A2780
Human Cancer Cell Lines. Toxicology In Vitro, 26(3), 462468

Behera, B.C., N. Verma, A. Sonone, U. Makhija. (2009). Optimization of Culture Conditions for Lichen Usnea ghattensis G. Awasthi to Increase Biomass and Antioxidant Metabolite Production. Food Technology and Biotechnology, 47(1), 7-12

Brodo, I.M.; Sharnoff, S.D.; \& Sharnoff, S. (2001). Lichens of North America. New Haven \& London: Yale University Press.

Fitriana, D. (2017). Inventarisasi Tanaman Obat dalam Ramuan Jamu Gendong di Kecamatan Panakukang Makassar. Skripsi. Makassar, UIN Alauddin Makassar

Handayani, L. (2008). Tanaman Obat untuk Masa Kehamilan dan Pasca Melahirkan. Jakarta Selatan : PT. Agro Media Pustaka. 
Herawati, Nuraida, \& Sumarto. (2012). Cara Pembuatan Simplisia. Jakarta: Departemen kesehatan RI.

Jannah, M., \& Afifah,N. (2020). Studi Kayu Angin (Usnea spp.) Sebagai Bahan Obat Tradisional, Studi Kasus: Pasar Tradisional Kota Jakarta. Teknosains, 14(1), 61-67.

Jannah, M. (2014). Variasi Genetik dan Identifikasi Usnea spp. Berdasarkan Karakter Morfologis dan Molekular. Tesis. Yogyakarta, Universitas Gadjah Mada

Kementrian Kesehatan. (2016). www.b2p2toot.litbang.kemkes.go.id

Luo, H., Y. Yamamoto, J.A. Kim, J.S. Jung, Y.J. Koh, J.S. Hur. (2009). Lecanoric Acid, a Secondary Lichen Substance with Antioxidant Properties from Umbilicaria antarctica in Maritime Antarctica (King George Island). Polar Biology, 32(7), 1033-1040.

Maulidiyah,I., Watu, M., and Nurdin M. (2016). Secondary metabolites identification from Lichen Usnea Longissima Ach: Bioactivity test of antibacterial. International journal of applied chemistry, 12 (3), 347-357.
Mulyani, H, Sri H.W., \& Venny I.E. (2016). Tumbuhan Herbal Sebaga Jamu Pengobatan Tradisional Terhadap Penyakit dalam Serat Primbon Jampi Jawi. Jurnal Penelitian Humaniora, 21(2), $73-$ 91.

Noer, I.S., \& Rani, R.I.. (2007). The Culture of Indonesian Lichen thalii of Usnea flexuosa Tayl. Simposium kebudayaan Indonesia-Malaysia ke-X. Universitas Kebangsaan Malaysia.

Ohmura, Y., (2012). A Synopsis of the Lichen Genus Usnea (Parmeliaceae, Ascomycota) in Taiwan. Memoirs of the National Museum of Nature and Science, 48, 91-137.

Ohmura, Y. (2001). Taxonomy Study of The Genus Usnea (Lichenized Ascomycetes) In Japan and Taiwan. The Journal of the Hattori Botanical Laboratory, 90, 1-96.

Septiana, E. (2011). Potensi Lichen Sebagai Sumber Bahan Obat :suatu kajian pustaka. Jurnal Biologi, 1, 1-5.

Tilaar, M. (2010). The green scince of jamu. Jakarta. PT Dian Rakyat.

Tiro, M. A. \& Arbianingsih. (2011). Teknik Pengambilan Sampel. Makassar: Andira Publisher. 